\title{
A Relational Reflection on Pandemic Nationalism
}

\author{
Pichamon Yeophantong ${ }^{1} \cdot$ Chih-yu Shih $^{2}$ iD
}

Accepted: 16 March 2021 / Published online: 1 June 2021

(c) Journal of Chinese Political Science/Association of Chinese Political Studies 2021, corrected publication 2021

\begin{abstract}
Drawing on the case of Wuhan, this article considers how nationalist discourses evolved in the Chinese context during the COVID-19 pandemic. It adopts a relational perspective to argue that, just as the COVID-19 pandemic has revealed countries' vulnerability to diverse forms of nationalism and the danger that this presents, it also reveals an irony: how despite being treated as a 'solution' to the pandemic, nationalism can only exist and thrive insofar as its alter or Other-represented by the novel coronavirus itself and, for some countries, the 'China threat' - also thrives. To prevent this from becoming a vicious cycle, the article contends that nationalism is no solution and that new thinking on coexistence is the vaccine needed for securing the post-COVID-19 world order.
\end{abstract}

Keywords China $\cdot$ COVID-19 $\cdot$ Nationalism $\cdot$ Relationality

\section{Introduction}

Despite the many contested definitions of 'nationalism', analyses of nationalism during the COVID-19 pandemic have tended to assume the existence of a collective understanding of the concept. However, should there be one common theme across the COVID-19 nationalism literature, it is that both the literature and the empirical phenomenon being studied constantly contradict themselves. Just as there is a rise in "bio-political nationalism," [1, 49, 88], "vaccine nationalism" as well as "medical nationalism" [12, 29, 43, 79], there is also a sense of distrust in science and medical experts [59]; and whilst there is competitive nationalism between states such as the United States (US) and China [14, 37, 86, 87], there is likewise internal

Chih-yu Shih

cyshih@ntu.edu.tw

Pichamon Yeophantong

p.yeophantong@adfa.edu.au

1 School of Humanities and Social Sciences, University of New South Wales at the Australian Defence Force Academy, Canberra, Australia

2 Department of Political Science, National Taiwan University, Taipei, Taiwan 
distrust and xenophobia against citizens of different ethnicities within each of these countries [11]. As such, although there are some common themes to be found, there is still no consensus regarding the impact of COVID-19 on nationalism. But what has become markedly pronounced over the course of the pandemic is how nationalism can be leveraged by politicians and other interest groups in both democratic and non-democratic regimes to advance their own agendas. And as the empirical evidence of growing racism as a result of COVID-19 attests [45], an intense polarization of views is what has come to define both in-group and out-group identities.

This article considers how an alleged rise in Chinese nationalism during the COVID19 pandemic has been manufactured through top-down and bottom-up processes by the state as well as by different 'relational communities' - that is, communities that are defined by solidarity and informed by common experiences, historical relationships, and the shared values of their members, in addition to an obliged belonging to a particular territorial or ethnic category. In this sense, the nationalism examined in this article amounts to an articulation of civic or ethnic-cultural loyalties, but can also be an expression of moral values (e.g. solidarity and sacrifice) that transcend these. This is arguably seen in the case of Wuhan city. A localized form of nationalism had depicted, early on, the city and its citizenry as a diseased Other; this, however, changed as the nationalist framing shifted to one that emphasized solidarity and unity against the pandemic.

This article also argues that Chinese nationalism has multiple sources. During the pandemic, these sources notably reached beyond the Chinese Communist Party (CCP). Indeed, the nationwide mobilization of medical staff, each of whom would bear their municipal, provincial or regional team-name, led to an unprecedented surge in public morale. Building pride on multiple fronts by those engrossed in Chinese nationalist sensibilities has become a means to construct a relational network of decentralized (i.e. CCP-neutral) nationalisms. In this way, a figurative decoupling from the People's Republic of China by some Western countries would only prove counter-productive, effectively 'pushing China into a corner' as it were. As Washington challenges Beijing to a geopolitical duel, acknowledging and analysing the role played by 'spontaneous' third parties can help to complicate, decentralize, and pluralize their respective nationalisms (see Fig. 1 for an example of a localized nationalistic expression).

\section{Surveying the Literature on Chinese Pandemic Nationalism}

Using the notion of Chinese 'pandemic nationalism' as a departure point, it becomes apparent how the existing English-language literature tends to view the problem of rising nationalism, in the case of China, as CCP manipulation. Critics observe how the disease was primarily managed by the authoritarian CCP in order to bring the citizenry under its control and also to expand its influence over the rest of the world. Together, such critiques reveal four assumptions that warrant further discussion:

1) Chinese people tend to be 'unthinking'. For example, regarding the use of nationalist ideology to reframe the Wuhan outbreak and subsequent developments, Fei 
Fig. 1 Weibo renganmian cartoon originally created by Chen Xiaotao(@陈小桃momo)

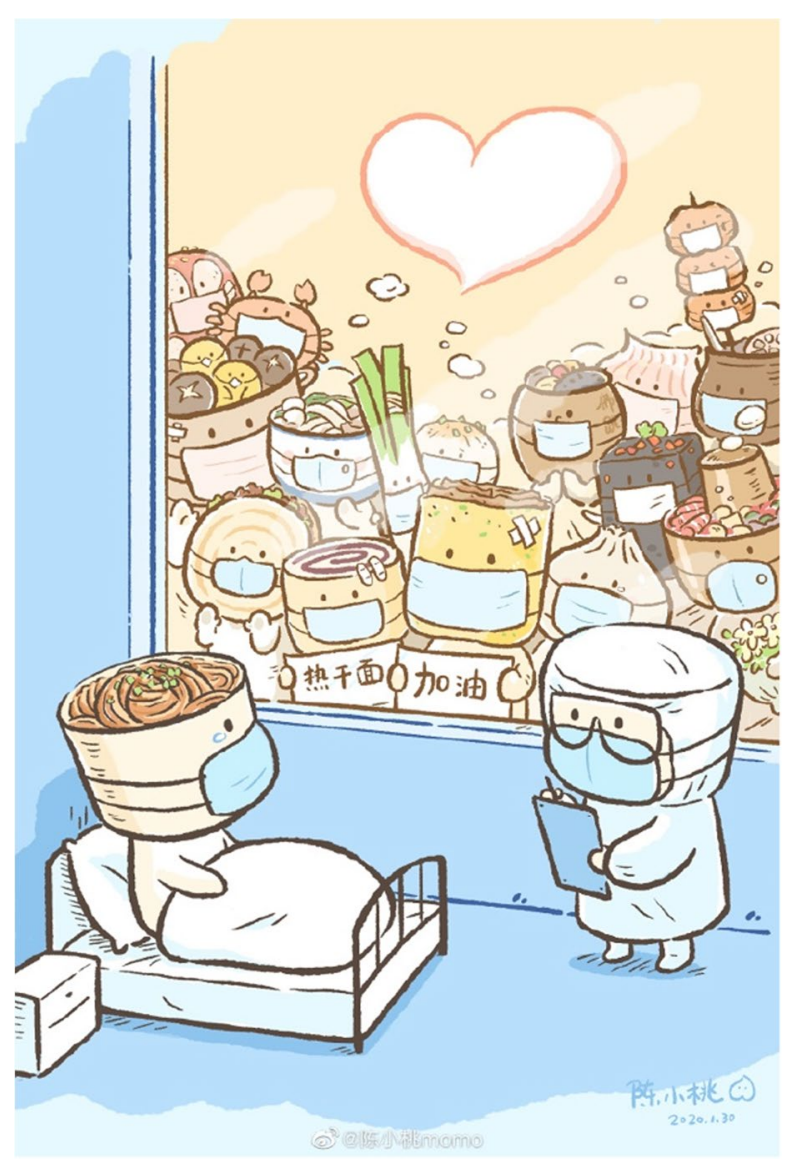

Yan [86] discovers that "the new government narratives resonated easily with the Chinese people, who had long been subjected to political indoctrination through the state-controlled media and schooling system." Moreover, according to Ming Mu's [52] statistics-based evidence, the Chinese people are believed to display a particular type of dark-triad personality composed of narcissism, Machiavellianism, and psychopathy which are driven by the subconsciousness rather than prudence.

2) Nationalism is primarily politically engineered. It is both a strategic and an emotional response to external accusations that point to China or Wuhan as the origin of the novel coronavirus. As Zhang and Savage [92] assert, "[t]he Chinese government is... upset with the US and its allies (Australia, Germany, European countries), who are insisting on a thorough investigation on the origins of the virus." Indeed, bans on travel from China had led to charges of racism by the Chinese government [79]. According to Hughes [79], the political motive of the Chinese government in this case is supposedly "to propagate the superiority of the "China Model" of politics, after the legitimacy of the Chinese Communist Party (CCP) was badly dented by the early mismanagement of the crisis." Similarly, Greenfeld 
[79] sees Chinese nationalism as amounting to a challenge to "the United States to a single combat, so to speak. Could you match us, President Xi essentially offered, in containing a pandemic?"

3) Chinese nationalism is a chronic phenomenon. It appears deeply-rooted in modern Chinese history with the underlying psychology still prevalent today. As Jaworsky and Qiaoan [10] posit, "The glorious memory of Imperial China and the bitter memory of a 'century of humiliation' serve as unifying factors for these nationalists and motivate them to exert pressure on Chinese foreign policy. Such pressure from nationalists has become one of the major reasons China has difficulties adopting more moderate foreign policy, especially in its interaction with the US."

4) Nationalism is basically a Chinese problem. Nationalism is believed to serve the purpose of enhancing the CCP's legitimacy. Liu Jiacheng [48] argues “[i]t also prioritize[s] the national over the personal. People's personal suffering was not to be totally forgotten but was only invoked to affirm collective loss and national resilience." Consequently, Liu continues, "[t]he overwhelming performance of national triumph and repression of personal narratives marked a turn in the state's cultural governance."

Viewed individually, these assumptions may appear valid; they are nonetheless inadequate or even misleading critiques, unless we also note the emergence of voluntarism in Wuhan, the city where the virus first broke out, which has contributed to the growth of localised sentiments of pride and solidarity among and beyond the city's residents. They, moreover, ignore how Tokyo and Taipei, both perceived as rivals by Beijing for different nationalist reasons prior to the outbreak, have acted completely differently to effect changes in their relationships with China during the pandemic. Finally, these assumptions overestimate the power of the Chinese government as an authoritarian regime, for as Breslin [15] observes "we should not imbue the Chinese leadership with total power, authority, and capacity. Even in a state as strong as this, state power has clear limitations - and crucially is much more limited than some of the official words of Chinese government seem designed to have us believe."

As the number of COVID-19 cases began to drop in China, the Chinese media and general public have trumpeted the country's success in containing the virus' spread and have hailed the crisis leadership of President Xi Jinping. But alongside national pride, xenophobia and schadenfreude have also risen in the country, as evidenced by social phenomena ranging from the mistreatment of foreigners to the mockery or blatant celebration of other countries' struggles to contain the virus' outbreak [55, 72]. That said, despite evidence of exacerbated racist sentiments during the pandemic, allegations of flaring exclusionary nationalism and xenophobia have been actively denied by the Chinese state [57].

Nationalism is widely believed to be a common tactic of the Chinese government to galvanize the public and reorient attention away from the state's alleged culpability vis-à-vis its initially delayed crisis response [69, 70, 94]. Many have also observed the use of nationalistic propaganda messages by the Chinese government to vindicate its strict control over the people and deflect criticism of their ineffective response [33]. From a cultural studies perspective, Kloet et al. looked 
at East Asia to examine how COVID-19 became an arena for nationalistic power struggles. Beijing's COVID-19 containment measures were widely celebrated in official statements and among the public on social media, stirring up both local and national pride or what Kloet et al. term "biopolitical nationalism" [42]. As China's stringent containment regime was applauded and supported, state control was not only justified but also viewed as necessary for success: here, "[t]he people were quickly represented as vulnerable, needing to be protected, monitored and interpellated as part of the virus-fighting machinery" [42]. As Kloet et al. aptly observe, "the latest trigger [of national pride] has become efficiency in the exercise of biopower, especially vis-a-vis the "inefficient West", [42].

Even so, it is noteworthy that the handling of the pandemic did initially trigger mass public dissatisfaction and outrage, with some observers describing the crisis as the country's "Chernobyl moment" [91]. The public had expressed anger over the government's early mishandling of the outbreak, including the death of Dr Li Wenliang, the shortage and mismanagement of PPE for medical personnel, and the authorities' initial cover-up of the COVID death toll [91]. However, as the virus' spread was contained in China, criticism and public discontent also began to dissipate. In their place were constructed and localised narratives that focused on the heroic sacrifices of individuals and the need for national unity, which were reminiscent of disaster nationalism [91]. These narratives perpetuated alongside government censorship and crackdowns on dissidents, as well as broader bureaucratic and technocratic changes related to the handling of this national health crisis. To the grand narrative of a heroic "war" against the virus was thus added a humane touch of compassionate stories. According to Zhang, these elements, also found in past nationalist campaigns, subsume dissatisfaction with the government under a sense of national pride and belonging [91].

However, Wong argues that, although COVID-19 has sparked similar crisis responses, it constitutes a distinct event that diverges from the previous nationalistic campaigns in China [78]. Along with the rise of a more aggressive "Wolf Warrior" diplomacy, he noted an inward pivot of Chinese nationalistic rhetoric as it shifted from targeting both foreign and domestic audiences to primarily the domestic population [78]. ${ }^{1}$ On the one hand, the global backlash against Beijing's early mishandling of the virus' outbreak had served to vindicate the hawkish rhetoric that emerged on behalf of "China", which saw some Chinese diplomats advancing the belief that their Western counterparts were unlikely to reciprocate or appreciate Chinese values of courtesy and harmony; on the other, these diplomats found that their "fortitude" was especially appealing to domestic audiences who, in turbulent times, are often "in search of impassioned, at times zealous, speech in defense of the Chinese nation" [78]. Given these conditions, Wong contends that, instead of active engineering, the domestic orientation of Chinese nationalism constitutes a by-product of the increasingly bellicose rhetoric against Chinese communities, businesses and individuals.

\footnotetext{
1 The "Wolf Warrior" diplomacy, named after two fiercely patriotic Chinese movies, is often used to describe Beijing's increasingly aggressive diplomatic offensive.
} 
A similar argument is also put forward by Zhang: the hostile international environment towards China during the pandemic has promoted binary thinking-that is, "the assumption of a binary opposition between a homogeneous China and a homogeneous 'West'" - which views any criticism of the Chinese government as helping the enemy's cause [91]. According to Zhao [93], "Chinese netizens on the one hand value deliberation when expressing their comments on the performance of China and other countries. On the other hand, due to the US-led external provocation to China... Chinese netizens show a confident but confrontational and xenophobic posture in the discourse." In the same vein, Wong [78] argues that the growing xenophobia in the West provides an opportunity for the Chinese government to frame itself as a defender of "all Chinese interests", and that any criticism of government responses to the crisis becomes the antithesis of the interests of the entire nation.

But while this aggressive political strategy seems to be mainly targeting domestic Chinese audiences, it has invariably undermined the nation's international reputation [60]. Susan Shirk has argued that China could have leveraged its containment of the virus as an opportunity to "emphasize its compassionate side and rebuild trust and its reputation as a responsible global power" [25]. Instead, the nationalistic rhetoric and assertive strategies have been derailing Beijing's ambition for a peaceful rise. In the current politicized context of COVID-19, many suggest that Beijing's propaganda campaign has alienated foreign audiences and undercut Beijing's ongoing efforts to attract global support [75].

Whilst the manifold risks posed by Chinese nationalism during COVID-19 are widely discussed among English-language scholarship and media, little discussion has taken place on Chinese-language platforms. Interestingly, Xijin $\mathrm{Hu}$, editor of the CCP's mouthpiece Global Times, was among those who voiced concern over digital nationalism, having posted an article condemning nationalist netizens who mock Western countries' struggles to contain the pandemic [34]. The article sought to "shout out to the outside world" that irrational nationalist and populist comments do not represent the voice of all Chinese people, and that the attitude in mainstream Chinese society is to promote mutual respect [34]. Among the Chinese-language literature found on CNKI at the time of writing, ${ }^{2}$ the only publication that addresses COVID-19 and nationalism in China is an article by Furong Peng, who points out the risks associated with the irrational development and expression of nationalism during a pandemic, and calls for the prompt readjustment of such sentiments. Adopting President Xi's latest political discourse of creating a "shared future for humankind" (renlei mingyun gongtongti), Peng warns against the irrationalization of Chinese nationalism, which "has not been conducive to maintaining social stability and may even have damaged China's image as a responsible country" [56].

By contrast, Zhongyun $\mathrm{Zi}$ has been one of the more vocal dissidents, drawing parallels between rising Chinese nationalism during COVID-19 and the Boxer Rebellion-the ultranationalist uprising in China at the turn of the eighteenth century against Western imperialism [96]. Zi equates the country's growing COVID19 nationalism with anti-Westernism and argues that such nationalist sentiments are

${ }^{2} \mathrm{CNKI}$ is the largest electronic collection of academic literature in China. 
"retracing a direct path to ideas that are in their essence anti-human, anti-science and a wholesale rejection of our shared humanity" [96]. She further stresses that xenophobic nationalists ultimately inflict negative consequences on their innocent compatriots. As she puts it, "those online thugs have their sights trained on their fellow Chinese and nothing they say has any effect on foreigners apart, that is, from generating considerable wariness and enmity towards China in every quarter" [96].

However, among the discussions of Chinese nationalism, an oft-overlooked element is the distinction between the CCP-influenced, top-down narrative and those that are spontaneously-formed around public opinion. According to Jo Kim, the Chinese public has played a more significant role than generally perceived in promulgating nationalist rhetoric and fending off dissent. In many cases relating to COVID-19, it was the patriotic public, rather than the government, who wielded the keyboard to accuse and shame "traitorous" individuals who were criticizing the country [41]. Similarly, Jessica Chen Weiss draws attention to the more nuanced, internal dynamics of Chinese nationalism. While the Chinese state seems to have reined in its nationalist rhetoric to some extent, nationalism has also put pressure on the government to "talk tough and placate domestic audiences", increasing the costs of constraining it [75]. Moreover, Weiss argues that nationalism, which is often characterized by expansionist motives, may be driven more by domestic demand and insecurity [76]. Finally, she argues that the more China leans on a nationalist push, the less concerned the US should be about China emerging as the strategic rival [75]. As has been widely observed, the growing nationalism in the name of China has stoked tensions with many foreign nations, consequently undermining Beijing's ambition for global leadership.

\section{Wuhan and Pandemic Nationalism}

As mentioned above, during the early stages of the COVID-19 crisis, public fear and anger in China had mounted over the inadequacies of the government's response to the then epidemic. On 7 February 2020, the topic "Doctor Li Wenliang passes away" topped the search list of Weibo (a media platform equivalent to Twitter used by locals in China) and attracted almost a billion views [84]. However, the search record was soon removed and disappeared, along with all related social media posts, just as three other trending hashtags demanding greater freedom of speech and an apology by the Chinese central government were also deleted [17, 84]. The public fury that grew over the authorities' slow response to inform the public and contain the epidemic was further intensified by the government's perceived rush to silence the public's mourning of Li, who was seen not only as a whistleblower but also a martyr.

Negative sentiments toward the government had then risen to an arguably unprecedented degree but proved ultimately short-lived. A recent survey published in June 2020 found that Chinese citizens have a high level of satisfaction with the government's overall COVID-19 response, especially toward the national-level leadership compared to the local authorities, which may reflect greater trust in and credibility 
of the central government [80]. Compared to the situation in early February, this could be attributed to the Party's strict censorship, propaganda, as well as a genuine (regained) confidence in the government that resulted from domestic successes in curbing the virus' spread. Notably, the media content in Chinese cyberspace during this period was marked by sentiments of national solidarity as well as varied nationalistic overtones. What this points to, in effect, is how the formation of nationalistic public opinion needs to be understood from both top-down and bottom-up perspectives [51].

Certainly, scholars have observed in recent years how "instead of trying to counter negative criticism", the Chinese state "reorients the public to the positive" [61]. Instead of the previous discourse of "suffering" for the greater good of national stability and development, "positive energy" has gradually become a prominent ideological discourse in China and one which was especially accentuated by local actions and initiatives amid the COVID-19 crisis [21]. State agencies called on the media across all levels to publicize human interest and heartwarming stories related to the pandemic, in order to spread "positive energy" within the country [58]. The news and social media were filled with countless stories of people "sacrificing their small home for the greater home (the country)" (she xiaojia wei dajia) — from passionate medics volunteering to travel deep inside affected areas, the nation's "SARS hero" and the grandfatherly figure of Doctor Zhong Nanshan, who was shown as sleepdeprived but still fighting on the frontline, to ordinary individuals who engaged in acts of kindness to support the national battle against the virus [97]. At the same time, Doctor Li Wenliang was incorporated into these narratives, having been "reclaimed" by the Chinese state as "one member of the medical team who fought heroically and made contributions and sacrifices in the epidemic control effort" [7]. Such emotional anecdotes came to dominate both the news and social media, serving to "veil the harsh realities" [8]. As Zifeng Chen and Clyde Yicheng Wang note, domestically, the undertones of suffering in a period of positive energy "aim more at creating rally-around-the-flag effects" [21].

In fact, in more localized discourses on COVID-19, the phrase "Wuhan jiayou" sparked some of the most notable acts of positive energy during the crisis. Jiayou, meaning literally "add oil," is a common Chinese expression used for encouraging people to persevere and remain strong. On the sixth day of the city's lockdown, the residents in Wuhan responded to an initiative circulated on social media to open their windows at 8pm and shout "Wuhan jiayou" in an act of solidarity [67]. This collective action served to 'lighten the mood' and boost the morale of the isolated residents; and, more significantly, it also demonstrated the 'human face' of the city to a broader national audience. Videos of Wuhan residents shouting jiayou and chanting patriotic songs on their balcony captured 'touching moments' that allowed people to see the city not as the origin of the epidemic, but as a victim and comrade in the battle against the virus as a common enemy. As the video went viral online, "Wuhan jiayou" started trending on Weibo, with Chinese netizens pledging their support for and solidarity with Wuhan during its lockdown.

As a unifying slogan, "Wuhan jiayou" has prompted other spontaneous initiatives at the local level that have subsequently gained considerable traction. For instance, widely circulated on Weibo was a cartoon depicting a personified bowl of Wuhan's 
signature dish, hot dry noodles (reganmian), as a quarantined patient while Chinese snacks from other regions press themselves against the window, cheering Wuhan on with signs saying "be strong, hot dry noodles" (reganmian, jiayou) [see Fig. 1]. The post attracted tens of thousands of reposts in one day, including on several state official accounts [24]. "Reganmian" soon became an endearing way to refer to the city and a symbol of national solidarity, which has since prompted many social media campaigns, including the trend of displaying solidarity with Wuhan by pairing photos of reganmian with one's own hometown signature noodle dish [83].

The phrase was also adopted and used by the Chinese state to demonstrate its solidarity with the people. When Premier Li Keqiang visited Wuhan after its lockdown, he chanted "Wuhan jiayou" with the people to rally support, consolidating the message that the government and people are fighting together [4, 67]. As previously noted, these mainstream narratives of community resilience and solidarity have consequently contributed to shifting the focus away from criticism of government authorities during the then unraveling crisis.

In addition to the unifying power of empathy, national pride also serves as another crucial element in local narratives that has engendered a greater sense of 'positive solidarity' based on 'we-feeling' as opposed to othering. Among the trending and popular social media posts and news reports, many would highlight the country's 'unparalleled achievements' compared to other nations. Examples included the widely circulated screenshot showing a COVID-19 patient's medical expenses that totaled over one million Chinese yuan. The caption read, "perhaps only in China, can the government cover all your medical expenses for coronavirus", while comments largely expressed pride and gratitude toward the country [73]. Another notable example that was seen to demonstrate 'China's power' was the construction of Huoshenshan and Leishenshan hospitals. With more than 30,000 workers working around the clock, the two makeshift hospitals were built in just over a week in response to the strained resources in Wuhan [71]. Applauding such achievements, the state media reposted praise expressed on Western social media regarding the "miraculous" construction, demonstrating how "China's speed" amazed international observers. This international recognition was likewise hailed by the Chinese public [85].

Interestingly, during the hospitals' construction, Beijing's state broadcaster hosted live-streams of the construction and provided real-time progress updates, which instantly went viral and attracted millions of netizens to join the "online supervision" (yunjiangong) of the projects [95]. The comments section was filled with messages of solidarity and support—such as "Cheer up China" (Zhongguo jiayou) and "Cheer up Wuhan" (Wuhan jiayou). Nicknames were given to hoists, forklifts and cement mixers, and later, viewers were even given the ability to vote for their favorite $[5,39]$. Although the voting system was promptly removed as criticism emerged around the de-personalization and disrespect for the hardworking laborers, popular discussions of the 'idolized' construction vehicles continued on social media, where people developed a sense of involvement and solidarity while consuming entertainment. The state was thus able to engage with more people, especially youths, by adopting and incorporating the fandom culture and social media trend of live-streaming, while at the same time popularizing the narrative of a "great and 
powerful nation." This was not the first time that the state had leveraged online subcultures. Back in 2019, thousands of "online warriors" were united under the call to protect "brother Ah Zhong" (A Zhong gege) - the personification of China that originated from within the fandom community and was endorsed by the state media-as they flooded Facebook with nationalist comments during the anti-government protests in Hong Kong [93].

Aside from these local-level narratives, China's COVID-19 aid has also contributed to forming a new, more 'outward-looking' theme. Neil Thomas has tracked references to "assuming the role of a great power" (daguo dandang) in the People's Daily, and found that the phrase had taken off since Xi Jinping assumed leadership and had surged in the first quarter of 2020 [2]. The narrative of China as a responsible great power underlies sentiments of national pride and confidence which, during the pandemic, was largely centered on discussions among the Chinese public on the scale and overseas reception of China's foreign aid. When China dispatched the largest volume of medical assistance that Serbia had then received to combat the pandemic, which led Serbian President Aleksandar Vucic to state that "the only country that can help us is China" $[35,36]$, his comments were popularly cited by news outlets and public accounts on WeChat, with posts celebrating the close relationship not only between the two countries, but also with other countries to whom China had been "selflessly" providing in-kind assistance and sending medical experts. China's goodwill and support became subjects of national pride, as they were touted by the public as reflecting China's shouldering of its great power responsibility and by the state as building a "community of shared future for humankind" [89].

Following this, it is equally noteworthy how, as the global infection rates surged and the state media hailed the efforts of the Chinese government amid the growing global crisis, an emerging narrative on social media came to compare China's exceptional performance in containing the virus with that of the "unenlightened" West, with many stating that other countries should "copy the homework" (chaozuoye) that China has done when facing the test of COVID-19 [90]. This catchphrase of "copy homework" draws on an obvious classroom metaphor, and views China's crisis response as the model for other countries to emulate in order to succeed. Popular posts and comments online would also rhetorically ask why other countries could not "copy China's homework", with some further lamenting how Western countries had wasted the time that China had "saved for the world" and others mocking countries that were still suffering heavily due to the virus' outbreak [68]. But while the phrase became popular, it also attracted considerable debate, as many pointed out the difficulties associated with implementing the best practice in a crisis and the immorality of schadenfreude [68]. Some, moreover, pointed out how the idea had homogenized the responses of different Chinese provinces and sidestepped issues such as the mishandling of the epidemic by Hubei's provincial authorities [40]. In fact, several observers stated that people who made the "copy homework" comments were loyal supporters of the CCP, even though the metaphor had been disavowed by the Chinese Ministry of Foreign Affairs [89]. Notably, these "copy homework" comments quickly disappeared once more Western countries began to more effectively distribute social benefits and COVID-19 relief packages to their populations [40]. 
Public opinion in China is, of course, not homogenous. By documenting her firsthand experiences in Wuhan in her diary, Chinese writer Fang Fang recorded people's struggles during the city's lockdown. Her diary was reported by the foreign media and attracted millions of domestic readers, albeit with mixed reviews. When plans to publish her diary entries in foreign languages became known in China, both state and public criticism swelled. The diary had appeared at a time when the US was actively pushing culpability onto China for its ineffective handling of the pandemic. For many Chinese people, alarm bells sounded when Fang Fang's diary received a 'suspicious' level of recognition in the Anglosphere. Many questioned the authenticity of her accounts, criticized her for a lack of patriotism and even labeled her a "traitor". Posts on Weibo denounced Fang Fang for capitalizing on the national crisis and "handing over the knife" to the West to place "unjustified" blame on China [10, 81]. Besides the public venting and shaming, more "reasonable" opponents declared that "China will reflect on its own problems but will never tolerate any interference from the outside world" $[18,82]$. Among these online discourses, many displayed the moral rules of a rather narrow-minded nationalism that sought to counter any voices that might strengthen negative narratives about China- $\mathrm{a}$ fact that has been further exacerbated by the increasingly polarized geopolitical context. Whereas patriotism might be perceived as the positive and reasonable expression of adulation and special concern that one feels for one's country, when such feelings become more defensive and are used to justify aggressive, hostile acts against others, they are transformed into racist and xenophobic nationalism. In Fang Fang's case, popular narratives in the public discourse legitimized assertive actions and rhetoric as a 'patriotic' response to 'nationalist' attacks on China by foreign Others.

Even so, as the Chinese public becomes more digitally connected and savvy about state propaganda, more have also come to express a lower appreciation of the waves of positive energy and emotional tropes that are designed to stir up public sentiment, with questions still being raised about government transparency and accountability [8]. During the COVID-19 pandemic, these emerging voices openly criticized the government. Although online discussions were heavily monitored and suppressed by ongoing state censorship, Chinese netizens were able to come up with innovative ways to evade censorship and spread critical messages [6]. In many cases, the propagandist messages had overreached and backfired publicly. For instance, when the Party's Youth League attempted to tap into the fandom culture by launching virtual idols, this was met with a tremendous backlash and demands for the government to focus on addressing the COVID-19 outbreak, as opposed to launching propaganda aimed at stirring up nationalistic sentiments [93]. Other events have also led to increased public discussion of social issues, such as the gendered stories in the state media which lauded nurses for returning to work only days after having an abortion, treating COVID-19 patients while being pregnant, or shaving their heads before joining the frontline $[9,46]$. Many people were similarly irritated by the exploitation of people's suffering for propaganda purposes, analogizing propaganda stories to eating "blood-soaked steamed buns" (renxie mantou), a well-known metaphor in Chinese culture that critiques profit-making at the expense of others [69]. The metaphor, also commonly used by opponents of Fang Fang to accuse her for capitalizing on a national trauma, was adopted by those who condemned the use of frontline 
workers by the state to provoke public gratitude and solidarity. As these critiques reveal, while 'feel-good' sentiments about the country became embedded in the romanticized sacrifices of frontline workers, they also opened up much-needed debate over issues that were obscured by these sentiments, ranging from workers' rights and gender equality to national healthcare, government transparency and accountability. In this way, state-led efforts at engineering nationalism during the COVID-19 crisis did not yield straightforward or necessarily favorable results. In the Wuhan case, nationalism took varied forms and arose from different sources but, ultimately, with each form being based on shared experiences of sacrifice and communal visions of solidarity.

\section{Chinese Nationalisms Compared and Reconsidered}

Nationalism is not always a binary construction in China's COVID-19 experience. Wuhan nationalism, as discussed above, illustrates this point. However, historically, Chinese nationalism has been defined by binaries of insiders and outsiders, patriots and betrayers, or simply you and me. While the binary seems conceptually indispensable, in practice, it has always been fluid. This is because the social roles of real persons are malleable, as their social and cultural relationships constantly evolve. Chinese nationalism can often give way to xenophobia, for example [47]. Here, the binary is between 'the Chinese' and 'the alien'. Whether or not a person is treated as an Other depends not on citizenship, language, skin and religion, which are stable, but on the relationships embedded in the context of their interactions. Therefore, an alien can be exempted from the exclusion usually applied to aliens, provided that she is able to convince her (perceived) Chinese counterparts that she is a friend of China. This can usually be achieved by arranging a proper ritual or gift-giving [64]. Noticeable examples of individuals who have 'crossed binaries' include Anson Burlingame, Pearl Buck, Edgar Snow, and Henry Kissinger. Inversely, a Chinese person may be subject to discriminatory treatment if she abandons her expected social role as a Chinese person. The binary of nationalism, accordingly, does not enforce a self/other frame strictly. The scope of the self is both contextual and processual; it is discursive as well as behavioral. This is likely to be true of all nationalisms, albeit to varying degrees.

The implication of 'crossing binaries' is that a solution to the politics of nationalism must be relational. There were always pre-existing relations that cut across binaries prior to the rise of nationalist sensibilities [11]. Once incurred, nationalism can unite as well as divide people-such is the politician's way of manipulating the relational lens to inspire practices that silence alternative lenses. The ability to feel each other's pain and struggle is testimony to the existence of relations. Nationalism is unique in the sense that the feelings for others are basically discursively or ideologically prepared, as opposed to other relations that are informed by practical life experiences. Only when nationalism can preach and compel its believers into sacrificing for a collective actor will it become a materialized relation and believers will feel something real for each other. This explains why the collective perception of large-scale sacrifice is conducive to the rise of 
nationalism. Wars are, therefore, a familiar measure in this regard. Pandemics are another. Confronting a perceived nationalist regime by an inversely perceived counter-force merely serves to substantiate its imagined collective sacrifice.

Efforts to curb Chinese nationalism during the period leading up to the Beijing Olympics in 2008 is a case in point. It was argued that Beijing would use the Olympics to boost Chinese nationalism (reminiscent of what Adolf Hitler had done for Nazi Germany). This seemed to make sense, given that members of the international community had used the Olympics as an opportunity to level global critique at China for various issues, including Tibetan human rights. The result was an upsurge in Chinese nationalism throughout the Olympic Games. However, this proved relatively short-lived, with Beijing spending the entire year of 2010 on preparing $\mathrm{Hu}$ Jintao's state visit to the US in January 2011. The cycle resembled the upsurge in nationalism during the period immediately following the bombing of the Chinese embassy in Belgrade by the United States in 1999. It was anticipated that the incident would give rise to a new May $4^{\text {th }}$ Movement, a nationalist movement that arose after the Paris Conference in 1919 and which was considered the origin of the Communist revolution. Yet, this failed to transpire as the world accepted China into the World Trade Organization in 2001.

In short, granted that the need to draw a boundary in order to protect an imagined nation has been the result of political campaigns and political correctness, sacrifice as a shared prior experience is required to make and reproduce the imagination of a political and moral community. This is, again, not unique to China, nor to the $\mathrm{Xi}$ regime. To the extent that the binary is politically obliged and lacks shared sacrifice, there will be no sincere attempt to define or sustain it in the long run. The political aspect of nationalism is thus doomed to lose steam after a while. Prior experiences and sentiments of sacrifice, such as during the COVID-19 outbreak, can instead nurture a conducive atmosphere for 'sustainable' nationalism. That is why the shutting down of Wuhan proved to be such an unconventional nationalistic turn. There was no clear human target or binary. The passion for togetherness is less a matter of performing political roles than an intuitive response to the participatory sense of human struggle and strength. The binary here is subjective. Those who have experienced the sacrifices of, and for, Wuhan would resent anyone who appears to disrespect such solidarity, including the unresponsive CCP-led, central government during the pandemic's early stages. Interestingly, in the United States, Miller-Idriss identifies a challenge to the "nation-state" as being the "ideological validation" that people will be searching for during the COVID-19 crisis, as opposed to "national identification". [66, 79]. This further and directly relates to people's support of the nationstate: if the state's policies identify with their ideology, they will support it; if it does not, then they will not support it [59].

That said, 'outside' literature has ostensibly been alarmed by the CCP's potential capacity to take advantage of Wuhan-bred nationalism, but analyses will remain superficial if they look away from how Chinese nationalist sentiments towards Wuhan have evolved. Wuhan's relative absence from COVID-19 nationalist literature is unsurprising. After all, Wuhan is neither a familiar nor sufficient site for the construction of a self-other binary, which is usually defined by imagined racial, statist, or civilizational differences and subject to international or national 
representation. Consider the dominance of the statist discourse at the international level, embedded in a Eurocentric worldview. Note also, for example, how in hindsight, the World Health Organization (WHO) officially announced the pandemic only after it had already hit Europe and the US. In fact, the official announcement of the WHO triggered 17 countries to adopt lockdown measures of varying degrees in a matter of days: 15 of these countries were European and two others were America and Australia. The immediate implication of the timing of this judgment reflects how the global South, including the postcolonial world of Asian countries in general-and China and Iran, specifically — was not regarded as sufficiently 'the world' despite the collective size of its population and territory. Such attitudes are likewise reflected in how, according to Japanese vice minister Aso Taro, his Italian counterpart had during the G7 teleconference responded in a lukewarm manner to Japan's suggestion of further cooperation to control the virus' spread because, for the latter, it was a disease of "yellow skinned people" [63]. Infamously, President Trump had similarly insisted on the racializing narrative of the "Chinese virus" rather than employing the official name of the disease.

To understand how the Wuhan experience might evolve into wider support for CCP-led nationalism, observers have adopted certain relational themes to explain away other relatively successful cases of managing the pandemic. These themes allude to the relevance of long-standing conditions that inform how people consciously belonging to the same communities relate. Specifically, these often concern cultural and colonial relationalities. To begin, colonial legacies engender psychological pressure on the postcolonial population to adopt the standard of civilization acquired from past colonial experiences. Although such pressure can breed a sense of inferiority, it simultaneously creates agency for adaptation, according to the perceived power matrix within a context. After all, conformity is the major theme in the literature on postcoloniality $[16,22,53]$. Postcoloniality thus implies the relative readiness of the former colonies to accept their vulnerability before any imagined alien force, including COVID-19. It is noteworthy that some commentators have attributed a higher ability to cope with COVID-19 to past colonial experiences, using the examples of South Korea, Singapore, Taiwan, Mongolia, Vietnam, and, arguably, New Zealand or even Ireland [77]. In the words of Fergal Bowers, "It's the actions of citizens that have brought Ireland to this precious position. This is an astonishing feat, not to be easily squandered" [13]. In addition to postcolonial conformity, the trust in authorities also allegedly has other sources. Some argue, for example, that the more effective COVID-19 responses are found in systems that are prone to illiberal democracy or authoritarianism, which enables stricter national monitoring and contact tracing [44]. In other cases, Confucianism is seen as a contributing factor [26]. Regardless of their veracity, these theories allude to the empowering relationalities of conformity and collectivism as necessary, albeit not sufficient, conditions for counter- or anti-pandemic performance. And as such, during the pandemic, these relationalities are believed to have contributed to greater systemic effectiveness.

Trying to salvage the reputation of democracy, Francis Fukuyama argues that it is all about state capacity and, therefore, the effectiveness of a state's response is completely unrelated to whether it is democratic or not. But the alleged failure of democratic theory to anticipate the importance of state capacity shifts attention away from 
practical suffering to the reputation of democracy itself. The non-relational theme of state capacity disguises postcolonial relationality at the national level and suffering at the subaltern level. In fact, state capacity itself is not a neutral term. It embraces an implicit criticism of the use of state capacity beyond disease control (for example, nationalist mobilization) and pre-empts praise for authoritarian effectiveness, but fails to appreciate the longing for recognition among the postcolonial population by the former colonial powers. As a result, China in general and Wuhan in particular appear to reproduce the image of a failing regime that embraces authoritarianism - an image that has already been popularized by the anti-extradition public demonstrations in Hong Kong, whereupon Beijing has vehemently defended its right to sovereignty. COVID-19 has thus worked to enflame old divisions, rather than uniting people [62].

Nevertheless, against this background, the current approach to CCP-led nationalism, through criticism and confrontation, is counterproductive. Worse still, such approaches camouflage the involvement of our own national sensibilities, which are themselves constituent components of the perceived Chinese nationalism [20]. As we watch and comment from an imagined external position, we simply reproduce the same binaries which drive CCP-led nationalism to engage assertively with the world. In actuality, at least two sources of Chinese nationalism are present-Wuhanbred and CCP-led. Wuhan-bred nationalism embraces shared experiences informed by the pandemic, one that does not have to include or exclude either Hong Kong, Taiwan or even Chinese citizens abroad, and which obliges the presumed members to subscribe to a digital system of control. Such pandemic/digital nationalism breeds a sense of security for those who willingly observe the disease's control- to be controlled is equivalent to being in control [42]. Discrimination against unspecified others, who are not under digital control orsecurity, is apparent but not required or fixed in terms of its boundaries. In contrast, the CCP-led nationalism includes all of those considered Chinese nationals and obliges them to support the state against rival foreign intervention. Even so, the standards for determining 'Chineseness' are always interactive, contextual, and hence unstable.

Mutual othering is therefore the wrong prescription for Chinese nationalism [23]. Yet, discursive othering is prevalent everywhere [19]: othering the virus as an alien intrusion, othering Wuhan's residents as the virus, othering China as the invaderall of which are to be excluded, quarantined, or discriminated against. All of this indicates the continuation of a deep-rooted condition of othering that stereotypes and reproduces a relationship between the virus and an imagined alien world [50]. However, it is exactly this delusional practice of othering that has camouflaged the embedded victimization within the structuration of class, gender, and the colonial legacy as well as race [38]. The CCP-led nationalism commits the same camouflaging fallacy, as it adopts an epistemological binary to judge between friends and adversaries. Boris Johnson, following his 'courageous' recovery from the disease, declared the coronavirus an "enemy" and has sought to lead a "national battle" against it [28]. This contrasts with his earlier "herd immunity" approach, which had sought to promote the coexistence of humans and the virus. Likewise, Trump's determination to 'decouple' from China had sought to take advantage of the othering discourse to create a strong sense of exclusion against China and/as the virus. 
Two other country cases-Taiwan and Japan-illustrate how democratic relationality can both commit and transcend nationalist othering. As one of the major (allegedly internal) targets of CCP-led nationalism, Taiwan is a key representative case of mutual othering thought. In fact, the state is engaged in a peculiar practice of selfothering or counter-nationalism. If othering refers to the construction of a self-other binary and hence, practices of exclusion, demonization, and discrimination against the other [27], then self-othering commits the same by further re-categorizing those presumably belonging to the scope of the self into the scope of the Other due to the imagined danger of the former's relationships with the other side. From the very beginning of the pandemic, in addition to officially and consistently enforcing the label of "the Wuhan virus" as a reference to the COVID-19 pandemic, Taiwan has victimized its own citizens and mainland Chinese individuals most closely related to Taiwan (i.e. those who have chosen to go to the 'other side' for study, work, or family reunions), in order to demonstrate that Taiwan is more Western than Chinese. This has gendered, colonial and illiberal consequences. In its long quest to join the West, as opposed to becoming part of greater China, the ruling pro-Taiwan independence party - the Democratic Progressive Party (DPP)—has cashed in on the opportunities offered by the pandemic to stigmatize Chinese spouses (usually wives) who had married Taiwanese people, and their families. After all, for Taiwanese people, who belong to the same Chinese ethnicity, the convenient way to display Taiwan's alienness to mainland Chinese is to mimic those who wish to exploit the pandemic in order to advance their racist agenda in the West. This was what the government of Taiwan did to Chinese students studying in Taiwan by refusing to allow them to return to Taiwanese universities along with other international students, even though some of the latter had come from areas suffering far more serious infection rates [65].

More significantly, when a couple of thousand Taiwanese people, who were visiting their Chinese relatives in Wuhan during the Chinese New Year Festival, became stuck in the city during the pandemic, Taiwan offered to repatriate them on government-chartered flights, an arrangement exclusively chosen to insinuate Taiwan's independent statehood: flying direct is crucial for the government because it symbolizes the sovereign action of evacuation - an action that the sensitive Chinese authorities accordingly rejected. In addition, only parents with a Taiwanese passport were allowed entry, not their children, who had to wait in long queues for their passports. As a result, many mothers naturally remained with their children in Wuhan. The message could not have been any clearer: anyone who had been potentially exposed to the "Wuhan virus" - as mentioned above, a term that the pro-Taiwanese independence forces had insisted all citizens in Taiwan must continue to use despite the virus' official name_-is discursively a Wuhan, not Taiwanese, 'resident'. When repeatedly asked during news conferences about the differing treatment of the banned Taiwanese who were visiting Wuhan and other returnees who were escaping from far more serious pandemic conditions in the United States and Europe, with the latter being allowed to enter, the official response was that the human rights of passengers from these latter countries must be respected.

Reversing its initial mission to rescue citizens from China, which is perceived as a foreign country, the DPP proceeded to ban them from returning to Taiwan entirely, 
unless this happened via a government-chartered flight directly from Wuhan, which were never available. Following the reopening of Wuhan, these passport holders or Taiwanese residents were still not allowed to return, as evacuation arrangements could not be arranged. In fact, the administrative measure adopted is racializing. The government recorded the names of all of the Taiwanese in Wuhan (collected initially for the purpose of arranging evacuation flights) in its immigration database so that, even if they were able to arrange transits at a third-country airport or a sojourn in a third country, they would still fail to pass at the passport control in Taiwan.

Deep in this background are the tens of thousands of families across the Taiwan Strait who know how to adapt to the politics and norms of both sides very well. They are not easily subjected to xenophobic mobilization, propaganda or disinformation, in effect providing an 'immunized' type of relational network for Taiwanese people to hedge against the allegedly dangerous Chineseness, touted by official de-Sinicization campaigns. Consider the binary-making and reproductive effects of the so-called China threat. These families, students, businesspeople and tourists, who obscure the binary, practice a form of political immunization by accumulating mutual lessons of how people on each side can cope with officially sanctioned difference or even enmity in their creative and reconciliatory, albeit politically 'incorrect', ways. This has contributed to discrediting the notion of the China threat. As such, the pandemic has been a necessary front for the government to strike back, substitute separation for immunity, and inflict self-othering. Thus, despite the sacrifice in human lives, the pandemic, in the words of Kloet, Lin and Chow [42], has made "many Taiwanese people feel safe, protected, and justified in pushing forward Taiwan's already existing nationalistic and exceptionalist agenda." However, as Florian Bieber [11] warns, "government responses to the pandemic risk turning fragile democracies into competitive authoritarian regimes. Such competitive authoritarian regimes might initially rely on the pandemic to justify repressive policies, but they are likely to turn to exclusionary nationalism as a key legitimizing ideology in order to sustain power."

Unlike the DPP-led counter-nationalism, civil society in Japan has displayed unexpected solidarity with the Chinese people during the pandemic. Practically, it is almost a copy of the Wuhan spirit with, metaphorically speaking, China being Wuhan and Japan being China. Indeed, a cultural means to restore a dented relationship is through gift-giving and ritualized reciprocal role-playing. This has been consistently so throughout the region's history of several thousand years. While the DPP had succeeded in constructing the equivalence of China with the virus and immediately claiming the political correctness of its counter-nationalist actions, Japan has been enmeshed in a rapprochement with China. What for Taiwan is a matter of constructing an existential threat from the deadly disease is, for Japan, an issue of solidarity. This lower level of perceived threat has further contributed to the de/construction of right-wing nationalism [31]. Massive support for China among the Japanese people at the beginning of the pandemic is the best metaphor for vaccinating a (political) antibody. Such displays of solidarity immediately 'melted the hearts' of the Chinese people who, generally speaking, have an intuitive distrust of Japan due to historical animosity. The resulting atmosphere of reconciliation requires neither the signatures of foreign ministers nor the initiation of a 'democratic peace' project. It also transcends national boundaries. 


\section{In Lieu of Conclusion: A Metaphoric Prescription for Nationalism}

National leaders, almost everywhere, will tend to call for nationwide support during a crisis or, in this case, a pandemic in the name of the nation and through attempts at stoking nationalism [3, 30, 32, 74]. But in the case of this ongoing global pandemic, this is not truly human othering, since COVID-19 is the only Other here. National governments also compete for face masks and vaccines, but this arguably echoes realism rather than nationalism. Realism can, conversely, result in an ignored effect. For example, nationalism is implicit in the recruitment of foreign low-waged nurses and doctors to serve on the dangerous frontline. When brought into the national consciousness, this kind of realist recruitment could inspire a binary sensibility. Medical realism of this sort resembles nationalism in a very particular way, since solidarity ends where the binary emerges. Even solidarity at the global level implies a binary-that is, humans v. the novel coronavirus. Whatever the scope, each imagined scope necessarily indicates a self-other binary.

Since the beginning of the pandemic, there have been at least two kinds of relational cleavages, from which nationalism, as the resulting third cleavage, distracts attention. One arises from the divides between and within nations or greater or smaller like-entities, caused by the structures of class, power and the severity of the pandemic, as well as the discursive practices of civilizational imagination, racial discrimination and partisanship. The level of personal risk, the ability to access self-help, and the opportunity for medical treatment all vary according to these relational settings. The other cleavage reflects the divide between the virus and humankind. There has been a clear focus in public discourses everywhere to conceive of the virus as alien to humankind. Through the clever manipulation of nationalism, this second estrangement amounts to the nationalization of the virus. However, the virus and humankind belong to the same ecology, rather than being external to each other as the public discourse has assumed. This, in effect, suggests the need for a post-human relational understanding. Such an understanding would require a certain degree of relational 'soul searching' in order to appreciate and sustain the mutual constitution and coexistence of all sides, each falsely conceived as an autonomous entity. The first divide undermines the solidarity that is essential for any human society to remain mutually beneficial. The second divide falsely externalizes what is actually internal, resulting in continuous self-estrangement. This process of selfestrangement requires further elaboration.

If the virus were alien to the ecology that supports humankind, then quarantines would be the best solution. Quarantine the virus, then the infected, the potentially infected, the heavily infected areas, the nation to which the area belongs, the ethnicity that stereotypically constitutes the nation, and then the civilization that stereotypically characterizes the ethnicity. Scapegoating of certain selected internal targets is inevitable when quarantining fails. Ultimately, however, no quarantine will fully succeed as the virus and humankind are ecologically connected through their shared belonging to nature. The best solution 
is to develop antibodies through a vaccine. The second-best approach would be to cultivate solidarity among the world population that relies on individual rather than national quarantining. In other words, the virus and humans must be mutually constituted to restore ecological relations in which the virus and humankind achieve mutual immunity.

A vaccine is thus an apt metaphor for a solution. Antibodies can help to rebuild an integrative community of the virus and humankind. Electoral/partisan rivals often portray the other side as the virus, as something alien, obnoxious and contagious. This indicates democratic failure and the rejection of solidarity. The externalization of a political rival is exactly how most COVID-19 policies have been considered and strategized. Yet the vaccine, once injected into the body, practically re-internalizes the virus. A political antibody is not unlike an intermediary process that brings mutually externalizing rivals together. The incurrence of such in-betweenness would help to develop the potential of postcoloniality and post-Western-ness to deconstruct these divides as well as reveal, revise and restore the ecological relations that already encompass all sides.

If we were to succeed in removing our COVID-19 antibodies (which is impossible), we would risk decoupling the body from the vaccine. Americans have developed 'China antibodies' for centuries. All kinds of Chinese social phenomena and cultural practices have already been transferred to the US. They are revisable and resilient-always transient and fluid, but never removable. In the sense that Americans have encountered, adapted to, and transformed Chineseness in various ways, they are already immune to the threat of Chineseness. In other words, Chineseness does not cause lethal problems in America. American Chineseness is like a vaccine that was initially acquired from encountered Chineseness. However, the Trump administration had effectively advised, during his four-year term, that these China antibodies should be removed in order to decouple from Chineseness, which was treated as a phenomenon of fabricated greatness due to the CCP's manipulation. What would happen to the mutually estranging world in this scenario does not bear thinking about.

In the longer term, however, as the virus and humans are commonly constituted by the same ecology and related in a prior ontology, quarantining will have to yield to the antibody/vaccine, through which humans and the virus can restore their coexistence. Let us consider the mutual relationality resulting from the complicated intersections between multiple relational communities as a metaphor for a vaccine that serves to immunize the democratic polity from othering practices towards 'yellow skinned' people, former colonies, Wuhan's residents, or China itself. Such spontaneous development of political immunity is arguably a registered human capability, regardless of culture or ethnicity [54]. Without this immunity, critical reflections on the structuration of the distribution of the pandemic as sharply disadvantageous to certain classes, races, occupations, and genders cannot emerge-nor can true democratic solidarity. 


\section{References}

1. Agamben, Giorgio. 2020. L'invenzione di un'epidemia [The Invention of an Epidemic]. Quodlibet. https://www.quodlibet.it/giorgioagamben-1-invenzione-di-un-epidemia. Accessed 30 Jan 2021

2. Albert, Eleanor. 2020. "How a Pandemic Drew China and Serbia Closer." The Diplomat, March 27, 2020. https://thediplomat.com/2020/03/how-a-pandemic-drew-china-and-serbia-closer/.

3. Albertoni, Nicolás, and Carol Wise. 2021. International Trade Norms in the Age of Covid-19 Nationalism on the Rise? Fudan Journal of the Humanities and Social Sciences. 14 (1): 41-66. https://doi.org/10.1007/s40647-020-00288-1.

4. Aljazeera. 2020. "Chinese premier visits Wuhan, epicentre of coronavirus outbreak." Aljazeera, January 28, 2020. https://www.aljazeera.com/news/2020/01/chinese-premier-visits-wuhan-epice ntre-coronavirus-outbreak-200127153309730.html.

5. Allen, Kerry 2020. "Coronavirus: Cement mixers become celebrities in China lockdown." $B B C$ News, January 31, 2020, https://www.bbc.com/news/world-asia-china-51315238.

6. Bandurski, David. 2020. "Coronavirus: The new and ingenious ways Chinese citizens are evading censorship to learn about the outbreak." Hong Kong Free Press, March 13, 2020. https://hongk ongfp.com/2020/03/13/coronavirus-new-ingenious-ways-chinese-citizens-evading-censorshiplearn-outbreak/.

7. Bandurski, David. 2020. "Reclaiming Doctor Li," China Media Project, March 19, 2020. http:// chinamediaproject.org/2020/03/19/reclaiming-doctor-li/.

8. Bandurski, David. 2020. "Turning on the Kitsch.” China Media Project, February 26, 2020. https:// chinamediaproject.org/2020/02/26/turning-on-the-kitsch/.

9. BBC News. 2020. "Coronavirus: Pregnant nurse 'propaganda' sparks backlash.” BBC News, February 21, 2020. https://www.bbc.com/news/world-asia-china-51583186.

10. BBC News. 2020. "Fang Fang: The Wuhan writer whose virus diary angered China." BBC News, May 18, 2020. https://www.bbc.com/news/world-asia-china-52712358.

11. Bieber, Florian. 2020. Global Nationalism in Times of the COVID-19 Pandemic. Nationalities Papers, First View, 1-13. https://doi.org/10.1017/nps.2020.35.

12. Bollyky, Thomas J., and Chad P. Brown. 2020. The Tragedy of Vaccine Nationalism: Only Cooperation Can End the Pandemic. Foreign Affairs 99 (5): 96-108.

13. Bowers, Fergal. 2020. "Covid-19 in Ireland: A Tale of Two Countries." Raidió Teilifís Éireann, April 18, 2020. https://www.rte.ie/news/analysis-and-comment/2020/0417/1132230-tale-two-count ries/.

14. Boylan, Brandon M, Jerry McBeath, and Bo Wang. 2021. US-China Relations: Nationalism, the Trade War, and COVID-19. Fudan Journal of the Humanities and Social Sciences 14:23-40. https:// doi.org/10.1007/s40647-020-00302-6.

15. Breslin, Shaun. 2010. "Great Expectations: (Competing Domestic Drivers of Chinese Policy Deliberations," VoxEU, April 16, 2010. https://voxeu.org/article/great-expectations-competing-domesticdrivers-chinese-policy-deliberations

16. Brissett, Nigel O.M., Reading conformity, resistance, and hybridity in jamaica's educational policy reform approaches. Journal of Postcolonial Cultures and Societies 4 (4): 82-116.

17. Cachero, Paulina. 2020. "The next Tiananmen Square? Chinese citizens are demanding increased free speech after the death of a coronavirus whistleblower doctor. China is censoring their calls." Business Insider Australia, February 8, 2020, https://www.businessinsider.com.au/calls-freespeech-online-doctor-li-wenliang-death-censored-china-2020-2?r=US\&IR=T.

18. Cao, Siqi. 2020. "Chinese vigilant on deifying writer Fang Fang amid publication of Wuhan diary in English.” The Global Times, April 8, 2020. https:/www.globaltimes.cn/content/1185055.shtml.

19. Cervinkova, Hana. 2020. Citizenship after COVID-19: thoughts from Poland. Social Anthropology 28 (2): 238-239.

20. Chan, Carol, and Maria Montt Strabucchi. 2020. Many-faced orientalism: Racism and xenophobia in a time of the nobel coronavirus in Chile. Asian Ethnicity 22 (2): 374-394.

21. Chen, Zifeng, and Clyde Yicheng Wang. 2020. The Discipline of Happiness: The Foucauldian Use of the "Positive Energy" Discourse in China's Ideological Works. Journal of Current Chinese Affairs 48 (2): 201-225. https://doi.org/10.1177/1868102619899409.

22. Davies, Matt. 2016. Everyday Life as Critique: Revisiting the Everyday in IPE with Henri Lefebvre and Postcolonialism. International Political Sociology 10 (1): 22-38. 
23. Diaz, Ileana I., and Alison Mountz. 2020. Intensifying fissures: Geopolitics, nationalism, militarism, and the US Response to the novel coronavirus. Geopolitics 25 (5): 1037-1044.

24. Ding, Xiaochen. 2020. Tianjin guniang de zhefu manhua huole 'wo zuixiang hua quanguo meishi jie reganmian chuyuan' [Cartoon by Tianjin girl went viral "hoping to draw it when all specialty dishes across the country welcome reganmian home from the hospital]. Tonight News Paper, January 31, 2020. https://www.sohu.com/a/369826586_571524. Accessed 30 Jan 2021.

25. Erlanger, Steven. 2020. "Global Backlash Builds against China over Coronavirus.” New York Times, May 3,2020. https://www.nytimes.com/2020/05/03/world/europe/backlash-china-coronavirus.html.

26. Escobar, Pepe. 2020. "COVID-19: Confucius Is Winning the Coronavirus War." Consortium News Vol. 29 April 16, 2020. https://consortiumnews.com/2020/04/16/covid-19-confucius-is-winningthe-coronavirus-war/.

27. Gover, Angela R., Shannon B. Harper, and Lynn Langton. 2020. Anti-Asian Hate Crime During the COVID-19 Pandemic: Exploring the Reproduction of Inequality. American Journal of Criminal Justice 45: 647-667.

28. Guardian News. 2020. Boris Johnson invokes wartime language amid coronavirus crisis: 'This enemy can be deadly'. March 17, 2020. https://youtu.be/1p3Ibx2dDVY. Accessed 30 Jan 2021.

29. Guimón, José, and Rajneesh Narula. 2020. Ending the COVID-19 Pandemic Requires More International Collaboration. Research-Technology Management 63 (5): 38-41. https://doi.org/10.1080/ 08956308.2020.1790239.

30 Gülseven, Enver. 2021. Identity, Nationalism and the Response of Turkey to COVID-19 Pandemic. Chinese Political Science Review 6 (1): 40-62. https://doi.org/10.1007/s41111-020-00166-X.

31. Hartman, Todd K. et al. 2020. The Authoritarian Dynamic During the COVID-19 Pandemic: Effects on Nationalism and Anti-Immigrant Sentiment. https://psyarxiv.com/4tcv5/download. Accessed 30 Jan 2021 .

32. He, Zhining, and Zhe Chen. 2021. The Social Group Distinction of Nationalists and Globalists amid COVID-19 Pandemic. Fudan Journal of the Humanities and Social Sciences 14 (1): 67-85. https:// doi.org/10.1007/s40647-020-00310-6.

33. Hernández, Javier C. 2020. "China Spins Coronavirus Crisis, Hailing Itself as a Global Leader." New York Times, February 28, 2020. https://www.nytimes.com/2020/02/28/world/asia/china-coron avirus-response-propaganda.html.

34. Hu, Xijin. 2020. Huxijin: Fandui Chaonong Oumei Zaonan Guojia, Fandui Ziwopengzhang [Xijin $\mathrm{Hu}$ : Against the mockery of America and European countries that are suffering, against self aggrandisement]. Huanqiu Wang, March 21, 2020. https://world.huanqiu.com/article/3xVoNcA0PHS. Accessed 30 Jan 2021.

35. Hu, Yuwei. 2020. "Serbia Embassy signs up for Weibo upon Chinese netizens' call." The Global Times, March 18, 2020. https://www.globaltimes.cn/content/1182955.shtml.

36. Hu,Yuwei. 2020. "Serbia attracts Chinese online fans as joint fight on virus enhances ties," The Global Times, 25 March 2020, https://www.globaltimes.cn/content/1183654.shtml.

37. Jaworsky, Bernadette Nadya, and Runya Qiaoan. 2020. The politics of blaming: the narrative battle between China and the US over COVID-19. Journal of Chinese Political Science. https://doi.org/10. 1007/s11366-020-09690-8.

38. Jerónimo, Patrícia. 2020. COVID-19 Nationalism and its toll on citizenship and mobility rights in European Union. UNIO EU Law Journal Blog. https://officialblogofunio.com/2020/04/20/covid-19nationalism-and-its-toll-on-citizenship-and-mobility-rights-in-the-european-union/. Accessed 30 Jan 2021.

39. Jie, Shan. 2020. "40 million online 'overseers' watch Wuhan speed building new hospitals for coronavirus patients.” The Global Times, January 30, 2020. https://www.globaltimes.cn/content/11779 63.shtml.

40. Jin, Zhe. 2020. Zhongguo kangyi 'chaozuoye' zhishuo de chuxian yu xiaoshi [The appearance anddisappearance of 'copy the homework' in China's COVID response]. VOA News Chinese, March 28, 2020. https://www.voacantonese.com/a/china---appearance-and-sudden-disappearance-of-copyt he-success-slogan/5349250.html. Accessed 30 Jan 2021.

41. Kim, Jo. 2020. "The Chinese People Step up to Enforce China's Nationalist Propaganda." The Diplomat, May 5, 2020. https://thediplomat.com/2020/05/the-chinese-people-step-up-to-enforce-chinas-nationalist-propaganda/.

42. Kloet, Jeroen de, Jian Lin, and Yiu Fai Chow. 2020. We are doing better: Biopolitical nationalism and the COVID-19 virus in East Asia. European Journal of Cultural Studies 23 (4): 635-640. 
43. Kohler, Jillian C., and Tim K. Mackey. 2020. Why the COVID-19 Pandemic Should Be a Call for Action to Advance Equitable Access to Medicines. BMC Medicine 18 (193): 1-3. https://doi.org/10. 1186/s12916-020-01661-3.

44. Kundnani, Hans. 2020. "Coronavirus and the Future of Democracy in Europe." Chatham House, March 31, 2020. https://www.chathamhouse.org/expert/comment/coronavirus-and-future-democ racy-europe.

45. Li, Hangwei. 2020. "Mistreatment of Africans in Guangzhou Threatens China's Coronavirus Diplomacy." The Conversation, April 17, 2020. https://theconversation.com/mistreatment-of-africans-inguangzhou-threatens-chinas-coronavirus-diplomacy-136348.

46. Li, Jane. 2020. "China is being accused of mistreating coronavirus nurses for propaganda." Quartz, February 19, 2020. https://qz.com/1804040/chinas-coverage-of-coronavirus-nurses-provokes-backl ash/.

47. Liao, Kuang-sheng. 1990. Antiforeignism and Modernization in China. Hong Kong: The Chinese University of Hong Kong Press.

48. Liu, Jiancheng. 2020. From social drama to political performance: China's multi-front combat with the Covid-19 epidemic. Critical Asian Studies 52 (4): 473-493.

49. Matthews, Jamie. 2020. 'Cultural Exceptionalism' in the Global Exchange of (Mis)Information around Japan's Responses to Covid-19. Media and Communication 8 (2): 448-451. https://doi.org/ 10.17645/mac.v8i2.3229.

50. Meinhof, Marius. 2020. Othering the Virus. Discovery Society (March 21). At: https://discoverso ciety.org/2020/03/21/othering-the-virus/. Accessed 30 Jan 2021.

51. Modongal, Shameer. 2016. Development of nationalism in China. Cogent Social Sciences 2 (1): 1235749. https://doi.org/10.1080/23311886.2016.1235749.

52. Mu, Ming. 2020. The Prevalence and Antecedents of Nationalism Conspiracy Theories During Covid-19 in China. Advances in Social Science, Education and Humanities Research 466: 334-341.

53. Nandy, Ashis. 1983. The Intimate Enemy: Loss and Recovery of Self Under Colonialism. New Delhi: Oxforc India Paperbacks.

54. Nordin, Astrid. 2016. Future beyond 'the West'? Autoimmunity in China's Harmonious World. Review of International Studies 42 (1): 156-177.

55. Pai, Hsiao-Hung. 2020. "The Coronavirus Crisis Has Exposed China's Long History of Racism." The Guardian, April 25, 2020. https://www.theguardian.com/commentisfree/2020/apr/25/coronavirus-exposed-china-history-racism-africans-guangzhou.

56. Peng, Furong. 2020. "Xinguan Feiyan” Yiqing Fangkong Beijing Xia De Zhonghua Minzurentong Yu Minzuzhuyi De Yingdui [Identity to the Chinese Nation and Response to Nationalism within the Context of the Prevention and Control of Covid-19]. Minzu Xuekan [Journal of Ethnology] 11 (1): 1-7, 119-20.

57. People's Daily. 2020. "Suowei "Feizhouren Zai Guangzhou Zaoshou Qishi” Yu Shishi Yanzhong Bufu [So-Called "Africans Face Discrimination in Guangzhou" Is Seriously Untrue]." People's Daily (Johannesburg), Arpil 16, 2020. http://world.people.com.cn/n1/2020/0416/c1002-31676666. html.

58. People's Court News and Media Headquarters. 2020. "Zhongyang zhengfawei yinfa tongzhi yaoqiu: fajue zhan"yi" dianxing jifa shehui zhengnengliang [Central Political and Legal Affairs Commission issued notice to explore typical examples of fighting the novel coronavirus and stimulate positive energy in the society]". February 18, 2020. http://www.court.gov.cn/zixun-xiangqing220051.html.

59. Perry, Samuel L., Andrew L. Whitehead, and Joshua B. Grubbs. 2020. Culture Wars and COVID19 Conduct: Christian Nationalism, Religiosity, and Americans' Behavior During the Coronavirus Pandemic. Journal for the Scientific Study of Religion 59 (3): 405-416. https://doi.org/10.1111/jssr. 12677.

60. Richburg, Keith B.. 2020. "Covid-19 Will Permanently Alter China's Relations with the World." Australian Strategic Policy Institute (ASPI), April 24, 2020. https://www.aspistrategist.org.au/covid19-will-permanently-alter-chinas-relations-with-the-world/.

61. Roberts, Margaret E. 2018. Censored: distraction and diversion inside China's Great Firewall. Princeton University Press.

62. Schertzer, Robert and Eric Taylor Woods. 2020. How Nationalism Can be a Force for Good in the Struggle against Covid-19. USAPP-American Politics and Policy Blog, April 9, 2020. https://bit.ly/ 2XsOtPj. 
63. Share News Japan. 2020. "麻生大臣: ’何の関係もない。あれは黄色人種の病気で俺達の病気じゃ ない"と誰が言ったんだ。お前じないか’と言ったのが第一回の会議”" [Minister Aso: “"It has nothing to do [with us]. That [COVID-19] is yellow people's disease, not our disease", someone said. Isn't that you?', was said during the first meeting.]. March 24, 2020. https://snjpn.net/archives/187001. Accessed 26 Mar 2020.

64. Shih, Chih-yu, and Chiung-chiu Huang. 2020. Competing for a Better Role Relation: International Relations, Sino-US Rivalry and Game of Weiqi. Journal of Chinese Political Science 25 (1): 1-19.

65. Staff Writer, Central News Agency. 2020. Protest to Decry Chinee Student Rules. Taipei Times (August 7). https://www.taipeitimes.com/News/front/archives/2020/08/07/2003741257.

66. Su, Ruolin, and Wensong Shen. 2021. Is nationalism rising in times of the COVID-19 pandemic? Individual-level evidence from the United States. Journal of Chinese Political Science 26: 169-187.

67. Su, Yvonne. 2020. "Coronavirus in Wuhan: Residents shout 'stay strong' from windows." The Conversation, January 31, 2020. https://theconversation.com/coronavirus-in-wuhan-residents-shoutstay-strong-from-windows-130851.

68. Times Weekly (WeChat Public Account). 2020. 'Chaozuoye' zheyang de chunhua, wo buxiang zaiting dierci [I don't want to listen to stupid comments like 'chaozuoye' again]. February 29, 2020. https://finance.sina.com.cn/wm/2020-02-29/doc-iimxyqvz6762015.shtml. Accessed 30 Jan 2021.

69. Tian, Ian Liujia. 2020. "Vampiric Affect: The Afterlife of a Metaphor in a Global Pandemic." Social Text Online, June 17, 2020. https://socialtextjournal.org/periscope_article/vampiric-affect-the-after life-of-a-metaphor-in-a-global-pandemic/.

70. Verma, Raj. 2020. China's Diplomacy and Changing the Covid-19 Narrative. International Journal 75 (2): 248-258. https://doi.org/10.1177/0020702020930054.

71. Wang, Jessica, Ellie Zhu, and Taylor Umlauf. 2020. "How China built two coronavirus hospitals in just over a week." The Wall Street Journal, Februany 6, 2020. https://www.wsj.com/articles/howchina-can-build-a-coronavirus-hospital-in-10-days-11580397751.

72. Wang, Vivian, and Amy Qin. 2020. "As Coronavirus Pandemic Fades in China, Nationalism and Xenophobia Flare." The New York Times, April 16, 2020. https://www.nytimes.com/2020/04/16/ world/asia/coronavirus-china-nationalism.html.

73. Wang, Yueming. 2020. Zhongzheng xinguanfeiyan huanzhe zhiliaofei chao baiwan, doushi guojia maidan [Medical expenses for each critically ill coronavirus patient cost over million, all covered by the country]. Sohu News, March 16, 2020. https://www.sohu.com/a/380474648_359980. Accessed 30 Jan 2021.

74. Wang, Zhongyuan. 2021. From Crisis to Nationalism? Chinese Political Science Review 6 (1): 20-39. https://doi.org/10.1007/s41111-020-00169-8.

75. Weiss, Jessica Chen. 2020. "China's Self-Defeating Nationalism - Brazen Diplomacy and Rhetorical Bluster Undercut Beijing's Influence.” Foreign Affairs, July 16, 2020. https://www.foreignaffairs. com/articles/china/2020-07-16/chinas-self-defeating-nationalism.

76. Wells, Callista. 2020. "Nationalism in the Wake of Covid-19 Hurts China's International Appeal, Says Cornell University Professor Jessica Chen Weiss." Freeman Spogli Institute for International Studies, June 3, 2020. https://fsi.stanford.edu/news/nationalism-wake-covid-19-hurts-china\%E2\% 80\%99s-international-appeal-says-cornell-university-professor.

77. White, Timothy J. 2010. The Impact of British Colonialism on Irish Catholicism and National Identity: Repression, Reemergence, and Divergence. Varia 35 (1): 21-37. https://doi.org/10.4000/etude sirlandaises.1743.

78. Wong, Brian. 2020. How Chinese nationalism is changing. The Diplomat. https://thediplomat.com/ 2020/05/how-chinese-nationalism-is-changing/. Accessed 30 Jan 2021.

79. Woods, Eric Taylor, Robert Schertzer, Liah Greenfeld, Chris Hughes, and Cynthia Miller-Idirss. 2020. COVID-19, nationalism, and the politics of crisis: A scholarly exchange. Nations and Nationalism 26 (4): 807-825.

80. Wu, Cary. 2020. "How Chinese citizens view their government's coronavirus response." The Conversation, June 5, 2020. https://theconversation.com/how-chinese-citizens-view-their-governmentscoronavirus-response-139176.

81. Xia, Meng. 2020. "Fang Fang's Wuhan diaries are a personal account of shared memory." The Conversation, May 19, 2020. https://theconversation.com/fang-fangs-wuhan-diaries-are-a-personalaccount-of-shared-memory-138007.

82. Xie, Echo. 2020. "Coronavirus journal Wuhan Diary continues to upset Chinese nationalists." South China Morning Post, May 3, 2020. https://www.scmp.com/news/china/society/article/3082575/ coronavirus-journal-wuhan-diary-continues-upset-chinese. 
83. Xinhua News. 2020. "Chinese netizens put their noodles together for virus-hit Wuhan." Xinhua News, February 1, 2020. http://www.xinhuanet.com/english/2020-02/01/c_138747797.htm.

84. Xiuhui Li. 2020. "Wuhanfeiyan "chuishaoren" Liwenliang guoshi: "yanlunziyou" cheng weibo resou, wangyou zhiyi ta "budehaosi" [Wuhan penumonia "whistle-blower" Liwenliang passed away: "freedom of speech" became Weibo hot topic, netizens raise doubts about his "miserable death"" The News Lens, February 7, 2020. https://www.thenewslens.com/article/130955.

85. Xue, Yanwen, Shang Gao, and Wenxuan Ma. 2020. "Huoshenshan shiri qiji, waiguo "yunjiangong" jinghu: zhiyou zhongguo keyi [Huoshenshan ten-day miracle: foreign "online supervisors" exclaimed: only China can!].” Xinhua News, February 6, 2020. http://www.xinhuanet.com/politics/ 2020-02/06/c_1125536113.htm.

86. Yan, Fei. 2020. Managing 'Digital China' During the Covid-19 Pandemic: Nationalist Stimulation and its Backlash. Posdigital Science and Education: At. https://doi.org/10.1007/ s42438-020-00181-w.

87. Yang, Yifan, and Xuechen Chen. 2021. Globalism or nationalism? The paradox of chinese official discourse in the context of the COVID-19 outbreak. Journal of Chinese Political Science 26: $89-113$.

88 Yi, Joseph, and Wondong Lee. 2020. Pandemic Nationalism in South Korea. Society. 57 (4): 44651. https://doi.org/10.1007/s12115-020-00509-z.

89. Yu, Xiaokui, and Zengkui Li. 2020. "Tuidong goujian renlei minyun gongtongti de zhongguo dandang [China's responsibility in promoting the construction of a community with shared future for mankind]." Chinese Central Government, May 27, 2020. http://www.gov.cn/xinwen/2020-05/27/ content_5515232.htm.

90. Zeng, Yunkun. 2020. "Home, Work, Homework, And Field." Antrhopology News, June 12, 2020. https://anthropologynews.report/home-work-homework-and-fieldwork/.

91. Zhang, Chenchen. 2020. Covid-19 in China: From 'Chernobyl Moment'to Impetus for Nationalism. Made in China Journal. https://madeinchinajournal.com/2020/05/04/covid-19-in-china-from-chern obyl-moment-to-impetus-for-nationalism/. Accessed 30 Jan 2021.

92. Zhang, J.J., and Victor R. Savage. 2020. The Geopolitical Ramifications of COFIC-19: The Taiwanese Exception. Eurasian Geography and Economics: At. https://doi.org/10.1080/15387216.2020. 1779773.

93. Zhang, Phoebe. 2020. China's communist youth idols get the thumbs down in coronavirus crisis. South China Morning Post, February 19, 2020. https://www.scmp.com/news/china/society/artic le/3051224/chinas-communist-youth-idols-get-thumbs-down-coronavirus-crisis. Accessed 30 Jan 2021.

94. Zhao, Suisheng. 2021. Rhetoric and reality of China's global leadership in the context of COVID19: Implications for the us-led world order and liberal globalization. Journal of Contemporary China 30 (128): 233-248.

95. Zhou, Ren, and Xinlan Li. 2020. 'Fanquanhua' Fansi - zainan zhong xuyao taiduo ziwo gandong he jiti kuanghuan ma?" [Reflecting on 'fandomisation' — do we neeed much self- and collective celebration amid disasters?]. Chawang [CWZG], February 10, 2020. http://m.cwzg.cn/theory/ 202002/54950.html?page=full. Accessed 26 Mar 2020.

96. Zi, Zhongyun. 2020. 1900 \& 2020 - An Old Anxiety in a New Era. China Heritage, 28 April 2020. http://chinaheritage.net/journal/1900-2020-an-old-anxiety-in-a-new-era/?utm_medium=email \&utm_content=6LhsAQ-CeP5HFTZuvJBfGrrvICUeFPUb-khVCWrSeQvnv2EgEbUnLuObh2 kffS9O. Accessed 30 Jan 2021.

97. Zou, Shuo. 2020. “'SARS hero' follows leads on illness.” China Daily, January 23, 2020. http:// global.chinadaily.com.cn/a/202001/23/WS5e28dd3ca310128217272df3.html.

Pichamon Yeophantong is an Australian Research Council DECRA Fellow and Senior Lecturer at the School of Humanities and Social Sciences, University of New South Wales at the Australian Defence Force Academy, Australia.

Chih-yu Shih teaches international relations theory, anthropology of Knowledge, and cultural studies at National Taiwan University. Access to his current research-Intellectual History of China and Chinese Studies—can be found at http://www.chinastudies.taipei/ 